\title{
Good Governance as a Tool of Sustainable Development
}

\author{
Ilija Stojanović ${ }^{1}$, Jovo Ateljević ${ }^{2}$, R. Stevan Stević ${ }^{3}$,
}

\begin{abstract}
Growing concern about environmental degradation, disappointment with development efforts to reduce poverty and inequality on a global scale together with economic and socio-political instability has shifted focus from the model of economic growth to the new model of sustainable development. Despite the new orientation of development economics, the question on how to achieve sustainable development goals still remains. In order to avoid failure of the neoliberal agenda, the revised version of Washington Consensus focusing on good governance has taken the leading role in development policy.

The aim of this research is to test the links between a fuzzy concept of good governance and very heterogonous dimensions of sustainable development. Our research aims to analyze the effects of good governance on particular indicators of sustainable development, especially of socio-economic development, at the level of different categories of countries.

This study reveals that statistical significance, direction and intensity of the effects of good governance dimensions vary in relation to the selected indicator of sustainable development and affiliation to the particular category of countries. These results suggest that there is no "one size fits all" model of good governance promoted as a universal mantra of sustainable development putting into question the principles of post-Washington consensus as the key response to modern developmental challenges.
\end{abstract}

Keywords: good governance, sustainable development

\section{Introduction}

Despite the economic growth in the era of neoliberal globalization the first round of the neoliberal reforms failed to reduce global poverty and inequality, which led to economic and political instability. This approach did not recognize the challenges which such development policy creates in terms of sustainable economic results. According to Demmers et al. (2004) high unemployment, poverty and inequality are explained by inefficient administration prone to corruption. In order to avoid failure of neoliberal agenda, the revised version of Washington Consensus has taken the leading role of development policy. According to post-Washington Consensus, the central place of development policy is occupied with the model of good governance which has become the mantra of development policy. Good governance is the new approach that recognizes the role of the state in the economy where the joint participation of state and non-state actors, civil society and private sector, is essential in the process of public governance.

Nevertheless, there is a doubt among scholars about positive effects of good governance

${ }^{1}$ Freelance researcher, Cvijete Zuzoric 5, 76100 Brcko, Bosnia and Herzegovina,

2 Faculty of Economics at the University of Banja Luka, Majke Jugovica 4, 78000 Banja Luka, Republic of Srpska-Bosnia and Herzegovina,

${ }^{3}$ Faculty of Economics Brcko at the University of East Sarajevo, Studentska 11, 76100 Brcko, Bosnia and Herzegovina, 
in achieving very heterogeneous sustainable development goals. Not everyone is convinced about the effectiveness of good governance. Brinkerhoff and Goldsmith (2005) believe that replacing bad institutions with good institutions can produce worse results for the society, citing the example of decentralization of power in Morocco under King Mohammed, which led to growth of the influence of radical groups in the country. Some recent examples come from Libya, Syria, Tunisia, Egypt and Ukraine where the attempts of "democratic changes" providing good governance did not provide political and economic sustainability. It is important to review the paradigm of good governance in order to determine how much the society actually receives from such model of public governance. Therefore, this study's main objective is to research and analyze the effects of good governance on very heterogeneous dimensions of sustainable development with special focus on socioeconomic development.

\section{Literature review}

Topics of sustainable development and good governance are very intertwined in literature. Sharma (2001) believes that good governance is the central issue of sustainability, while Bosselmann et al. $(2008$, p.6) argue that it is also the prerequisite for achieving sustainability. However, they should be perceived as two concepts, especially bearing in mind their roots. Demmers et al. (2004) suggest that, contrary to the idea of sustainable development with roots in circles which request a dedicated approach to environmental protection issues, understanding of good governance comes from the World Bank in the light of an analysis of the situation in sub-Saharan Africa. In this regard we will dedicate this section to review of the literature that explains the features of two concepts and how they may be related.

\subsection{From economic growth to sustainable development}

In the period from the fifties to the eighties the dominant approach to development was based on orientation to increase the economic growth (Khan, 2007). After the World War II the main issue for developed countries was to maintain the economic growth while developing countries focused their attention on achieving the target of GDP growth which would, as it was assumed, automatically lead to a higher level of quality of life (Wang et al., 2008).

Some scholars point out the difference between growth and development and scholars are slowly beginning to embrace these differences. According to Banik and Yoonus (2012) the economic growth is a univariate concept measured purely on the basis of increasing in GDP per capita and much narrower concept compared to the development which is seen as a multivariate concept aimed at achieving quality of life. Stiglitz (1998) also perceives the importance of GDP growth but expresses the need to adopt a broader development focus. According to him GDP per capita is a means but not an end to improvement of living standard, health and education conditions and reduction of poverty. Leichtová et al. (2007) suggest that the growth in GDP per capita says little about real conditions in which people live. Soubbotina (2004) believes that the sustainable economic growth in developing countries is crucial for reducing poverty and 
increasing the standard of living, but also argues that economic growth is not enough. Nayyar (2006) indicates that the last half of the twentieth century has been characterized by enormous economic progress in the world based on a significant level of growth of global GDP. He also indicates that around 830 million people suffer from malnutrition, while 1.2 billion have no access to clean water, and even 2.7 billion people have no access to adequate sanitation facilities. Some scholars warn that despite the substantial economic growth and industrialization of many countries, the level of poverty continues to increase (Minujin et al., 2002; Plewes et al., 1996). According to Mitlin (1992), economic growth does not contribute to enrichment of the majority of population. In favor of this claim is the fact that $1 \%$ of the richest population has the same amount of income as the poorest 57\% of the population (De La Barra, 2006). Ayub (2013) warns that too much inequality is destructive to economic growth, noting that the equality of income is an important precondition for sustainable development.

The institutionalization of the approach of sustainable development appears after the adoption of the report Our Common Future in 1987 by the World Commission on Environment and Development of the United Nations, known as the Brundtland Report. This report provided the most famous definition of sustainable development "development that meets the needs of the present without compromising the ability of future generations to meet their own needs" (UNWCED, 1987).

According to Yamaguchi (2003), sustainable development represents the ideology of development strategies that need to solve previous destructive effects on development. Rees (2002) points to the growing criticism of expansionist theory that is closely related to the neoliberal paradigm where the economy is seen as an independent, self-regulating and self-sustaining system. Having in mind that the model of good governance is a child of neoliberal ideology, there is a growing concern about the possibility that this will ensure balanced approach to different and very heterogeneous values of sustainable development. In this regard, Mitlin (1992) warns that there is little agreement on how to achieve sustainable development goals.

\subsection{A paradigm shift towards good governance}

By the end of the Cold War poor governance in communist countries could not be sustained anymore. Attention was focused on the nature of political regimes in the developing world and, together with policies oriented to the market, given to good governance (Hout, 2007). Moreover, unequal results from the first round of neo-liberal reforms through structural adjustment programs from the eighties led to criticism of the Washington Consensus and the legitimacy of the international financial institutions, especially because of creation of highly unregulated global market (Craig and Porter, 2006).

The shift in the principles of neoliberal development agenda came from the inside with significant impact of Joseph Stiglitz who, in his capacity of Vice President and Chief Economist of the World Bank, proposed a new agenda of economic development oriented towards the goals of sustainable development (Gore, 2000; Fine, 2003; Öniş and Şenses, 2003; Hout, 2007). The post-Washington Consensus focused its attention on institutional issues, social justice and inclusiveness which stood opposite to the early neo- 
liberalism ideas that had lost their credibility and capacity because of founding on interests of elitist groups working in favor of transnational capital (Margheritis and Pereira, 2007). According to Argyriades (2006) good governance or governance without government allows a new vision in which private and public sector together with the civil society participate in division of power.

This paradigm shift from the neo-liberal structural adjustment programs refers to more inclusive program of poverty reduction and good governance which would allow the creation of broader consensus on the issue of economic growth led by market with the involvement of poor countries in global capitalism (Craig and Porter, 2006). In this respect, good governance as a concept enabled the salvation of the Washington Consensus (Demmers et al., 2004). De Angelis (2003) argues that the paradigm of governance is not a transition from neoliberal practice, pointing out that it is essentially the central element of respective phase when neoliberals faced numerous challenges in achieving results and solving problems in the economy. Parnini (2009) indicates that even by the end of the Cold War, the notion of development was focused on exporting Western values and institutions through principles of conditionality by introducing good governance by major donors and international financial institutions. According to him, this approach represents "development aggression" carried out by Western donors.

Although some authors like Thomas (2009) claim that there is clear evidence of poverty reduction as a result of the economic growth during the last 25 years, Öniş i Şenses (2003), (2003) argue that the poverty rate has been reduced due to a good performance in Asia, especially in China where the neoliberal reforms have been omitted. In favor of this claim Todaro and Smith (2003) indicate the experience of East Asia and China, which have shown high economic growth with poverty reduction, noting that these are also the countries where the application of the principles of the Washington Consensus was limited. Having in mind these concerns, this raises a crucial question: Does the application of the model of good governance enable sustainable development?

Regarding the effects of good governance on economic growth, there are very opposing views among scholars. Sharma (2007) points out that a significant number of econometric analyses show a strong correlation between a long-term economic performance and good governance. Grindle (2010) also points to the analysis conducted by the World Bank indicating significant evidence that good governance is essential for sustainable development measured by per capita income. However, Rodrik (2008) points to the examples of certain countries such as China, Vietnam and Cambodia in which the economic growth is clearly shown in spite of the lack of good governance. Empirical research conducted by Khan (2007) indicates a very weak positive relationship between the quality of governance and the economic growth. This author argues that the positive relationship between these two variables is co-dependent due to the inclusion in the research sample of a large number of developed countries that have a high value of indicators of good governance and the majority of developing countries that have low levels of the economic growth and indicators of good governance. Having all this in mind, we have set up our first general hypothesis:

H1: Application of the model of good governance, regardless of the achieved level of economic development, significantly contributes to the improvement of sustainable development with special focus on the economic growth. 
Related to the question of poverty, some scholars observe good governance as an instrument which helps in overcoming poverty (Kioe Sheng, 2010; Shylendra i Bhirdikar, 2005). However, there are very different opinions on this issue. According to Shepherd (2000) good governance may be necessary but not sufficient for poverty reduction. This author points out that the reform of public administration based on the reduction of public expenditures can have bad consequences in efforts to reduce poverty. Grindle (2004) warns that we should carefully analyze reforms that contribute to good governance, which are of particular importance for poverty reduction. The author therefore advocates the introduction of the concept of good enough governance with the aim of reducing poverty, which includes multi-layered understanding of the capacity of institutions and governments, with the understanding that all things cannot be implemented at once. In this regard, we have set up our second general hypothesis:

H2: Application of the model of good governance, regardless of the achieved level of economic development, significantly contributes to the improvement of sustainable development with special focus on poverty reduction.

Although it is believed that the neo-liberal concept of development contributes to the economic growth, De La Barra (2006) considers that the results of economic growth based on neo-liberal principles are useful only for a small group of people, which leads to increase in inequality. In this regard, Haque (1999) argues that economic inequality contributes to the further enrichment of the influential classes. Yi and Woo (2014), with their empirical research, have not been able to confirm the hypothesis that democracy associated with good governance leads to more equitable redistribution of income. The two authors explain these results of the effects of redistribution in the democracies as a result of the practice of lobbying and influence of interest groups that provide resources to political parties. This raises doubts about the impact of good governance on reducing inequalities; therefore we have set up our third general hypothesis:

H3: Application of the model of good governance, regardless of the achieved level of economic development, significantly contributes to the improvement of sustainable development with special focus on reducing inequality.

In literature there are different views on the effects of certain dimensions of good governance on particular indicators of sustainable development which create further doubts about" one size fits all" approach of governance reform advocated by international financial institutions. Kim (2009) suggests that the socio-economic development depends on the specific aspects of governance, but not fully out of the whole package. Different views on the relationship and influence of the model of good governance on sustainable development indicate the need for additional empirical research which is the central theme of this study.

\section{Methodology}

This study is aimed at discovering the specific links between different dimensions of good governance and very heterogeneous goals of sustainable development, not only at a general level but also in the context of different categories of countries. Bearing in mind the multi-dimensionality of both concepts, this study will look into whether and to what extent there is a relationship between the individual 
dimensions of good governance and individual dimensions of sustainable development with focus on socio-economic development.

The basic layer of the analysis includes consideration of the effects on sustainable development of two different research models: the aggregate model of good governance and the disaggregate model of good governance. The aggregate model of good governance can be represented by simple linear regression model:

$Y_{0}=a+\beta_{0} X_{0}$

- $Y_{0}$ - dependent variable (selected indicator of sustainable development), namely:

- GDP per capita (source: World Bank) as a measure of economic growth;

- Poverty Headcount Ratio at 2 USD a Day (source: World Bank) as a measure of poverty;

- GINI Index (source: World Bank) as a measure of inequality;

- $\quad X_{0}$ - independent variable represented by average value of six different dimensions of good governance within the Worldwide Governance Indicators (WGI). In order to determine the specific links between the individual dimensions of good governance and the selected variables of sustainable development, we set up the disaggregate model represented by multiple linear regression model:

$Y_{0}=a+\beta_{1}\left(X_{1}\right)+\beta_{2}\left(X_{2}\right)+\beta_{3}\left(X_{3}\right)+\beta_{4}\left(X_{4}\right)+\beta_{5}\left(X_{5}\right)+\beta_{6}\left(X_{6}\right)$

- $\quad Y_{0}$ - same as in the aggregate model;

- $X_{1}$ - independent variable represented by the WGI Voice and Accountability;

- $\quad X_{2}$ - independent variable represented by WGI Political Stability and Absence of Violence;

- $\quad X_{3}$ - independent variable represented by the WGI Government Effectiveness;

- $\quad X_{4}$ - independent variable represented by the WGI Regulatory Quality;

- $\quad X_{5}$ - independent variable represented by the WGI Rule of Law;

- $\quad X_{6}$ - independent variable represented by the WGI Control of Corruption;

In addition to basic research layer, we conducted cross-sectional layer of the research that is pervasive to the above mentioned model. The cross-sectional layer of our research was based on different types of the research samples: aggregate and disaggregate sample. Thus, we conducted analyses of both models in total, or aggregate sample of $\mathrm{N}=215$ countries for period from 2000 to 2012, with the total number of observations for respective interval $\mathrm{N}_{\mathrm{t}}=2795$.

Based on the UN classification of countries (UNDESA, 2012) adapted for this study, we disaggregated the total sample into five different categories of countries: (1) developed, (2) transition, (3) developing, (4) non-developed, and (5) small island countries. This approach allowed us to carry out the analyses of both models from the basic layer at the level of each of the individual categories of countries, or each disaggregate research sample.

Although we set the general hypotheses, in order make possible the implementation of research methodology, we also set up two working hypotheses. Below are listed the null working hypotheses that we used in conducting our empirical research: 
$\mathrm{wH}_{(0)}$ : Application of good governance as the aggregate model does not contribute to increase in the value of [selected indicator of sustainable development] and $\mathrm{wH}_{(0)}: \beta_{0}=0$

$\mathrm{wH}_{(0)}$ : The model does not include any dimension of good governance which explains [selected indicator of sustainable development $]$ and $\mathrm{wH} 2_{(0)}: \beta_{1}=\beta_{2}=\beta_{3}=\beta_{4}=\beta_{5}=\beta_{6}=0$

Once we have collected and classified data from several statistical databases, we applied the method of statistical analysis that allowed us to test the established models and to test the hypotheses. With the aim of testing the working hypotheses, we used OLS regression; simple regression in case of the aggregate model of good governance and multiple regression in case of the disaggregate model of good governance.

\section{Empirical results}

\subsection{Effects of Good Governance on Economic Growth}

During the analysis of the correlation between Good Governance and GDP per capita we found that the correlation coefficient $\mathrm{R}=, 734$ which is very high. According to the regression analysis we found that $F(1 ; 1.954)=2.286 ; \mathrm{p} \leq, 05$ meaning that the aggregate model of Good Governance is statistically significant for predicting positive changes in the value of the dependent variable. Therefore, we reject the null $\mathrm{wH}_{(0)}$ hypothesis for the total sample. The equation of simple linear regression reads as follows:

$Y_{0}=12.685+11.595\left(X_{0}\right)$
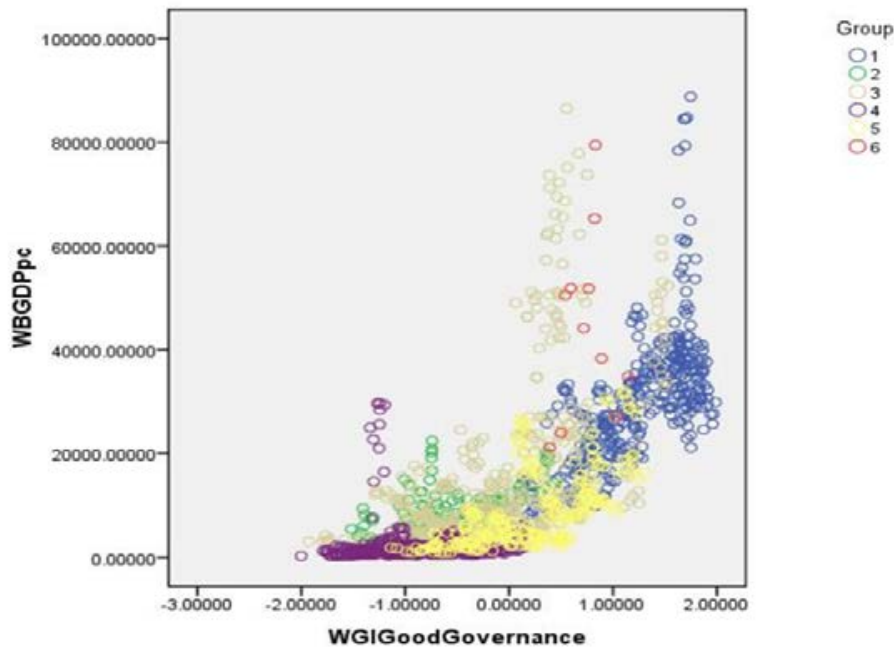

Figure 1: Correlation between good governance and economic growth

Going in more detailed analysis of the relations within the individual categories of countries we found very different results. In case of non-developed countries the model is not statistically significant $(p=, 077)$ for predicting changes of the dependent variable. 
Therefore, we accept the null $\mathrm{wH} 1_{(0)}$ hypothesis in this particular case meaning that Good Governance as the aggregate model does not contribute to increase in the value of GDP per capita in case of non-developed countries. In any other case, we found statistically significant effects of Good Governance on dependent variable. We reject a the null hypotheses $\mathrm{wH} 1_{\mathrm{n}(0)}$ for $\mathrm{n}=1,2,3,5$ categories of countries.

In multiple regression analysis we found the result $F(6 ; 1.954)=600 ; \mathrm{p} \leq, 05 ; \mathrm{R}=, 805$; $\mathrm{R}^{2}=, 648$. This result confirms that the model is statistically significant for predicting changes in the dependent variable which allows rejection of the null $\mathrm{wH}_{(0)}$ and acceptance of the alternative hypothesis for the total sample suggesting that at least one dependent variable is included in the model. Based on the equation of multiple regression, it is shown that all dimensions of Good Governance are statistically significant predictors for the dependent variable:

$Y_{0}=12.597-6.071\left(X_{1}\right)+1.287\left(X_{2}\right)+3.730\left(X_{3}\right)+4.567\left(X_{4}\right)+3.173\left(X_{5}\right)+4.215\left(X_{6}\right)$

This equation indicates that the variable Voice and Accountability has a negative impact on GDP per capita for the whole sample. Through multiple regressions within the different categories of countries, we confirmed the statistical significance of the model in each case. Therefore, we reject a set of the null $\mathrm{wH} 2_{\mathrm{n}(0)}$ hypotheses for $\mathrm{n}=1,2,3,4,5$. However, the individual dimensions of Good Governance have very different effects on GDP per capita at the level of different categories of countries.

\begin{tabular}{|c|c|c|c|c|c|c|c|c|c|c|}
\hline & \multicolumn{2}{|c|}{ Developed } & \multicolumn{2}{|c|}{ Transition } & \multicolumn{2}{|c|}{ Developing } & \multicolumn{2}{|c|}{ Non-developed } & \multicolumn{2}{|c|}{ Small island } \\
\hline & $\beta$ & $\mathrm{p}$ & $\beta$ & $\mathrm{p}$ & $\beta$ & $\mathrm{p}$ & $\beta$ & $\mathrm{p}$ & $\beta$ & $\mathrm{p}$ \\
\hline a & 5250 & 0,105 & 10813 & 0 & 11870 & 0 & 261 & 0,362 & 7562 & 0 \\
\hline$X_{1}$ & 6054 & 0,161 & -83 & 0,912 & -8310 & 0 & -2028 & 0 & 1502 & 0,035 \\
\hline$X_{2}$ & -2361 & 0,1 & 2925 & 0 & 2503 & 0 & 2311 & 0 & 1905 & 0,039 \\
\hline$X_{3}$ & -4062 & 0,142 & 6407 & 0 & 2899 & 0,092 & 131 & 0,823 & 5835 & 0 \\
\hline$X_{4}$ & 2852 & 0,258 & -1729 & 0,093 & 3415 & 0,015 & 62 & 0,889 & 1482 & 0,105 \\
\hline$X_{5}$ & 18408 & 0 & -253 & 0,886 & -3387 & 0,044 & -6 & 0,992 & -2490 & 0,025 \\
\hline$X_{6}$ & -2071 & 0,319 & -20 & 0,989 & 11788 & 0 & -2548 & 0 & 1052 & 0,273 \\
\hline \multicolumn{11}{|c|}{ Stepwise } \\
\hline & \multicolumn{2}{|l|}{$\beta$} & \multicolumn{2}{|l|}{$\beta$} & \multicolumn{2}{|l|}{$\beta$} & \multicolumn{2}{|l|}{$\beta$} & \multicolumn{2}{|l|}{$\beta$} \\
\hline$a$ & \multicolumn{2}{|l|}{10310} & \multicolumn{2}{|l|}{10919} & \multicolumn{2}{|l|}{12160} & \multicolumn{2}{|l|}{219} & \multicolumn{2}{|l|}{8025} \\
\hline$X_{1}$ & & & & & \multicolumn{2}{|l|}{-8209} & \multicolumn{2}{|l|}{-1977} & \multicolumn{2}{|l|}{1483} \\
\hline$X_{2}$ & & & \multicolumn{2}{|l|}{2889} & \multicolumn{2}{|l|}{2112} & \multicolumn{2}{|l|}{2324} & & \\
\hline$X_{3}$ & & & \multicolumn{2}{|l|}{6276} & & & & & \multicolumn{2}{|l|}{6822} \\
\hline$X_{4}$ & & & \multicolumn{2}{|l|}{-1860} & & & \multicolumn{2}{|l|}{ 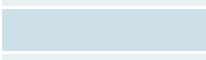 } \\
\hline \multirow{2}{*}{$\frac{X_{5}}{X}$} & \multicolumn{2}{|l|}{15222} & & & \multicolumn{2}{|l|}{3804} & & & & \\
\hline & & & & & 11257 & & -2454 & & & \\
\hline
\end{tabular}

\subsection{Effects of Good governance on Poverty}

The analysis of correlation between variables Good Governance and Poverty 
Headcount Ratio at 2 USD a Day shows correlation coefficient $\mathrm{R}=-, 507$. The value of the correlation coefficient indicates a moderate negative relationship between the two variables. The coefficient of determination is $\mathrm{R}^{2}=, 258$ which means that the independent variable in this case explains only $25,8 \%$ of the change in the dependent variable. However, when it comes to the value of the model there is still a statistically significant level of prediction of the dependent variable. This conclusion we draw from the result $F(1 ; 405)=140 ; \mathrm{p} \leq, 05$. We can therefore reject the null $\mathrm{wH} 1_{(0)}$ and accept the alternative hypothesis for the total sample thus confirming that Good Governance still contributes to the reduction of poverty at statistically significant level. We have found the regression equation which reads:

$Y_{0}=26,7-14,6\left(X_{0}\right)$
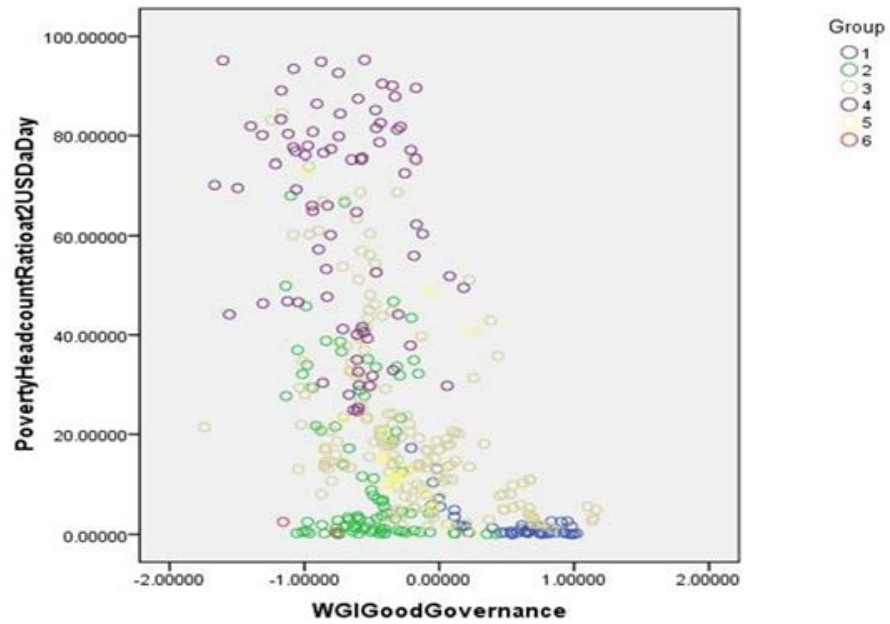

Figure 2: Correlation of good governance and poverty

During regression analysis for individual categories of countries we found the absence of statistical significance of the model in two cases: non-developed $(p=, 079)$ and small island countries $(p=, 086)$. For other categories of countries different degrees of the effect of Good Governance on poverty reduction are achieved. These results require the rejection of the following set of the null hypotheses $w H 1_{n(0)}$ for $n=1,2,3$ categories of countries and the acceptance of the null hypothesis for $n=4,5$.

The analysis of multiple regression model shows that the variable Regulatory Quality $(p=, 190)$ is not statistically significant for the model. Using stepwise analysis, we have reached statistically significant model in five steps with the following results $F(5 ; 401)=41,99 ; \mathrm{p} \leq, 05 ; \mathrm{R}=, 586 ; \mathrm{R}^{2}=, 344$. In this respect, we reject the null $\mathrm{wH} 2{ }_{(0)}$ hypothesis for the total sample. We have found multiple regression equation:

$Y_{0}=25,86-5,97\left(X_{1}\right)-10,59\left(X_{2}\right)-28,88\left(X_{3}\right)+21,44\left(X_{5}\right)+8,42\left(X_{6}\right)$

From the equation above, we found even two variables that affect the increase in the Poverty Headcount Ratio at 2 USD a Day. This is especially the case for the variable Rule of Law, but the effect is present for the variable Control of Corruption as well. Through multiple regressions within individual categories of countries we have identified 
the existence of the statistical significance of the model in each case. Therefore, we reject a set of the null $\mathrm{wH}_{2}(0)$ hypotheses for $\mathrm{n}=1,2,3,4,5$. However, it is clear that individual dimensions of Good Governance have different statistical significance for the prediction, including differences of direction and intensity of impact on the dependent variable.

\begin{tabular}{|c|c|c|c|c|c|c|c|c|c|c|}
\hline & \multicolumn{2}{|c|}{ Developed } & \multicolumn{2}{|c|}{ Transition } & \multicolumn{2}{|c|}{ Developing } & \multicolumn{2}{|c|}{ Non-developed } & \multicolumn{2}{|c|}{ Small island } \\
\hline & $\beta$ & $\mathrm{p}$ & $\beta$ & $\mathrm{p}$ & $\beta$ & $\mathrm{p}$ & $\beta$ & $\mathrm{p}$ & $\beta$ & $\mathrm{p}$ \\
\hline a & 16,284 & 0 & 8,355 & 0,041 & 16,697 & 0 & 56,423 & 0 & 25,748 & , \\
\hline$X_{1}$ & $-2,95$ & 0,346 & $-13,708$ & 0,001 & $-8,136$ & 0 & $-3,099$ & 0,56 & 24,748 & , \\
\hline$X_{2}$ & $-2,939$ & 0,007 & $-9,994$ & 0,001 & $-7,02$ & 0 & $-7,016$ & 0,063 & $-68,454$ & , \\
\hline$X_{3}$ & $-2,967$ & 0,142 & $-23,24$ & 0,002 & 2,31 & 0,627 & $-29,488$ & 0,004 & $-43,249$ & , \\
\hline$X_{4}$ & $-7,666$ & 0 & 19,109 & 0,001 & 4,124 & 0,289 & $-12,066$ & 0,114 & $-43,994$ & , \\
\hline$X_{5}$ & 0,519 & 0,814 & 23,721 & 0,017 & 5,63 & 0,227 & 49,652 & 0 & 44,859 & , \\
\hline$X_{6}$ & 4,188 & 0,008 & $-9,184$ & 0,272 & $-12,358$ & 0,003 & $-8,884$ & 0,294 & 56,668 & , \\
\hline \multicolumn{11}{|c|}{ Stepwise } \\
\hline & \multicolumn{2}{|l|}{$\beta$} & \multicolumn{2}{|l|}{$\beta$} & \multicolumn{2}{|l|}{$\beta$} & \multicolumn{2}{|l|}{$\beta$} & \multicolumn{2}{|l|}{$\beta$} \\
\hline$a$ & \multicolumn{2}{|l|}{14,261} & \multicolumn{2}{|l|}{9,316} & \multicolumn{2}{|l|}{17,106} & \multicolumn{2}{|l|}{57,761} & \multicolumn{2}{|l|}{25,748} \\
\hline$X_{1}$ & & & & & $-7,897$ & & & & 24,748 & \\
\hline$X_{2}$ & \multicolumn{2}{|l|}{$-3,327$} & \multicolumn{2}{|l|}{$-10,463$} & \multicolumn{2}{|l|}{$-8,161$} & \multicolumn{2}{|l|}{$-7,469$} & \multicolumn{2}{|l|}{$-68,454$} \\
\hline$X_{3}$ & & & & & & & \multicolumn{2}{|l|}{$-38,555$} & \multicolumn{2}{|l|}{$-43,249$} \\
\hline$X_{4}$ & \multicolumn{2}{|l|}{$-9,085$} & & & & & & & $-43,994$ & \\
\hline$X_{5}$ & & & & & & \multirow{2}{*}{\multicolumn{2}{|c|}{38,786}} & \multicolumn{2}{|l|}{44,859} \\
\hline$X_{6}$ & \multicolumn{2}{|l|}{2,102} & & & & & & & \multicolumn{2}{|l|}{56,668} \\
\hline
\end{tabular}

\subsection{Effects of Good Governance on Inequality}

The analysis of correlation between variables Good Governance and Inequality of Income Distribution shows quite a weak negative correlation $(\mathrm{R}=-, 103)$. The coefficient of determination $\mathrm{R}^{2}=, 011$ is even weaker, indicating that good management explains only $1.1 \%$ of the change in the dependent variable. Still, our regression analysis provides the result $F(1 ; 459)=4,90 ; \mathrm{p}=, 027(<0,05)$ allowing us to conclude that the model is still statistically significant for predicting changes in the dependent variable. Regardless of the low degree of correlation, we reject the null wH1 $1_{(0)}$ hypothesis for the total sample meaning that Good Governance is statistically significant predictor of dependent variable. The linear regression equation is:

$Y_{0}=41,72-1,08\left(X_{0}\right)$ 

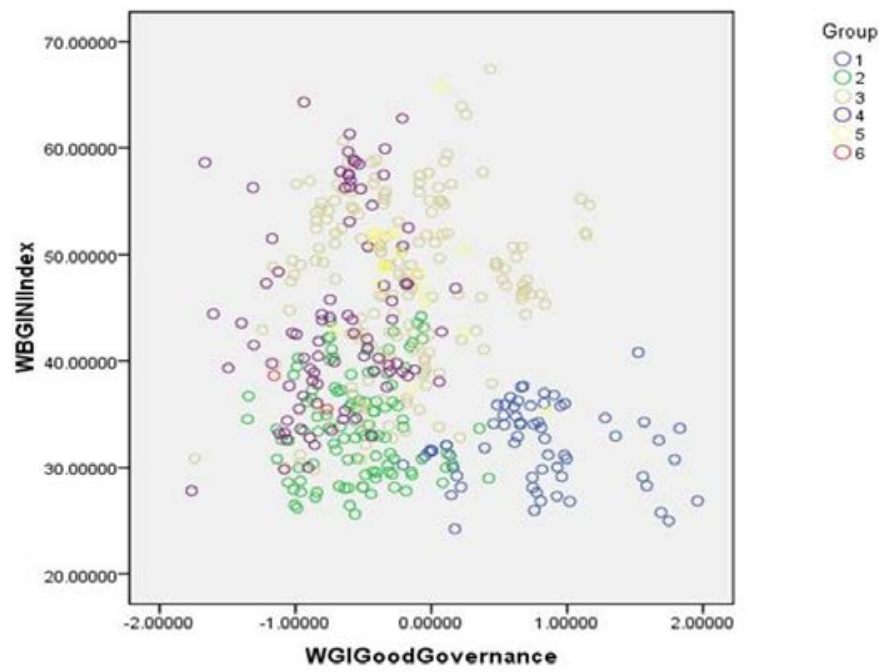

Figure 3: Correlation of good governance and inequality

As the ratio is negative, we conclude that the aggregate model of Good Governance at the level of total sample contributes to increasing equality. Within the analysis of regression within the individual categories of the countries we have reached very interesting results. Namely, we found that the model is not statistically significant in any of the identified categories of countries, except in developing countries. Even in this case the evaluation of statistical significance is quite at risk given that $\mathrm{p}=, 046$ with the coefficient $\beta_{0}=1,774$. These results indicate the need for accepting a set of null hypotheses $\mathrm{wH}_{\mathrm{n}(0)}$ for $\mathrm{n}=1,2,4,5$ and rejecting the null hypothesis $\mathrm{wH} 1_{\mathrm{n}(0)}$ for $\mathrm{n}=3$ with the risk $\mathrm{p}=, 046$.

During the multiple regression analysis, we determined the value of $F(6 ; 454)=24,63 ; \mathrm{p} \leq, 05$ which points to the need to reject the null hypothesis $\mathrm{wH} 2(0)$ for the total sample. Based on enter method we found that variables Government Effectiveness $(p=, 060)$ and Regulatory Quality $(p=, 750)$ do not have statistically significant value to the model. Additional stepwise analysis trough five steps determined the following results $F(5 ; 455)=29,59 ; \mathrm{p} \leq, 05 ; \mathrm{R}=, 495 ; \mathrm{R}^{2}=, 245$. As part of this analysis, we get the equation:

$Y_{0}=41,68+6,09\left(X_{1}\right)-2,87\left(X_{2}\right)-2,69\left(X_{3}\right)-9,80\left(X_{5}\right)+8,56\left(X_{6}\right)$

From the previous results it can be concluded that the variable Control of Corruption and Voice and Accountability increase the inequality in income distribution among the population. During multiple regression within the different categories of countries, we found that the model is not statistically significant only in developed countries $(p=, 061)$. This result leads to the conclusion that there is the need to reject a set of null hypotheses ${ }_{w H} 2_{n(0)}$ for $n=2,3,4,5$ and to accept the null hypothesis $w H 22_{n(0)}$ for $n=1$. 


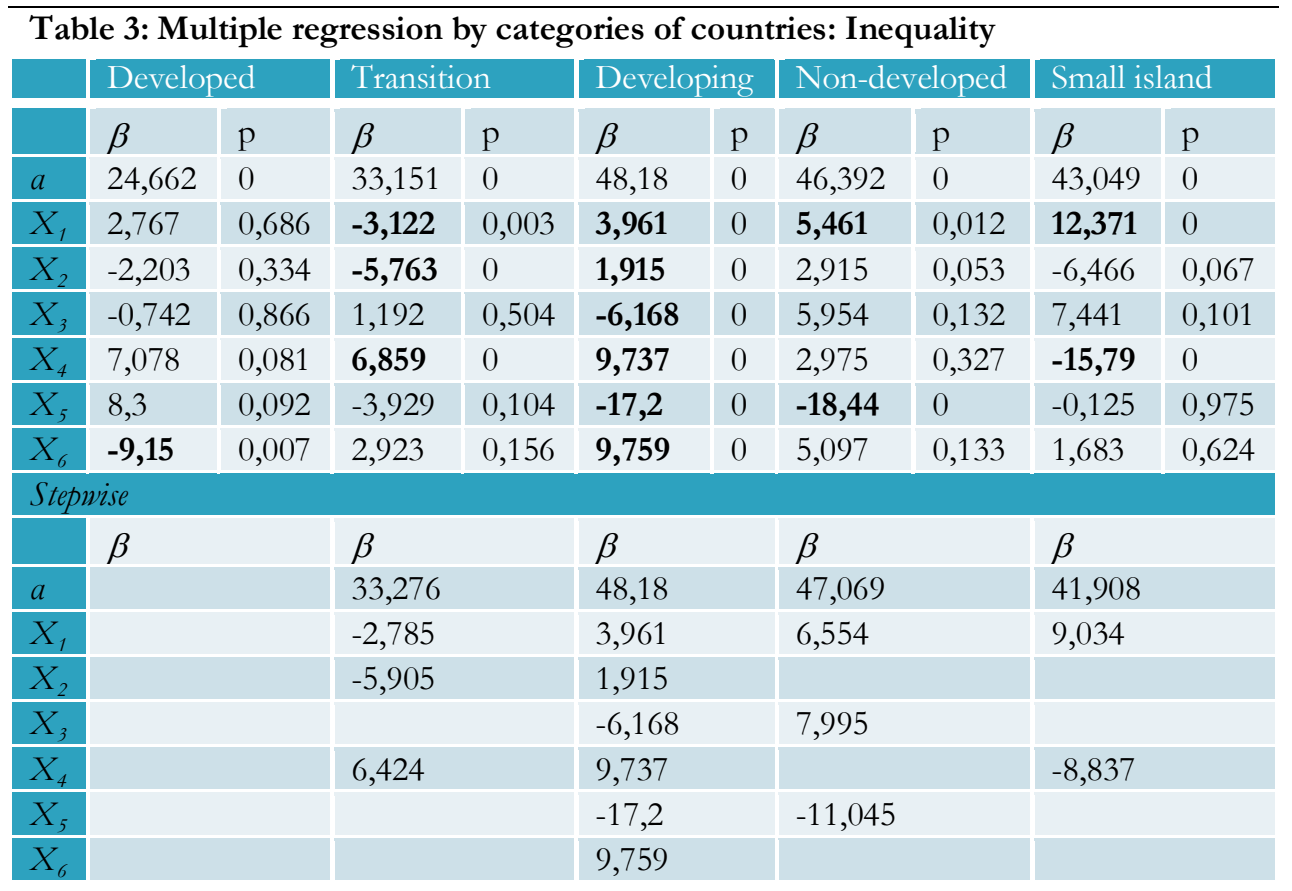

\section{Discussion}

How many times have you heard about good governance and the necessity to apply this model? Indeed, the term sounds very fine. Making it more times to hear about good governance it is becoming an increasingly necessary and conventional issue in the process of public sector reform.

By applying the concept of good governance, the international financial institutions as promoters of the new neoliberal approach seek to correct the mistakes that have been made by previous aid programs. On the basis of the empirical results we can join a group of scholars who express doubts about the model of good governance as the universal recipe for achieving sustainable development. If we compare the empirical results for different categories of countries, we can draw a clear conclusion about the absence of identical rules. Therefore, we agree with the views expressed by the Kemp and Parto (2005) that there is no single form of good governance that can achieve sustainability. The findings suggest the validity of Kim's (2009) thesis according to which social and economic developments do not depend on the whole package of good governance but only on certain aspects of good governance.

From the empirical results we have learned that depending on the particular objective of sustainable development which is to be achieved, this affects the optimal combination of dimensions of good governance to be used in the most effective way. This understanding of the relationship between good governance and sustainable development is in accordance with the example given by Grindle (2004) who explained that if the reduction 
of poverty is defined as a priority then it should be empirically tested which reforms are of major importance. Moreover, the empirical results clearly suggest that there is no single recipe for reform measures in the context of the application of the model of good governance acceptable to the different categories of countries. This can be explained by the existence of different development needs that arise from very diverse countries. These specificities of different countries require adaptation of reform efforts in area of public governance in order to achieve development objectives in different socioeconomic contexts. Any unified approach could lead to development aggression mentioned by Parnini (2009), and lead to un-sustainability of its socio-economic system.

Besides differences in the level of statistical significance and intensity of the impact of certain dimensions of good governance on particular indicators of sustainable development, there are also differences in direction of the individual dimensions of good governance to sustainable development indicators. In certain cases we got the results that show a negative impact of certain dimensions of good governance on sustainable development indicators. These results at first glance may seem surprising, especially because of the current theoretical views about the impact of good governance. As one example, our empirical study has placed a large sign of doubt above the positive effects of control of corruption as a dimension of good governance in each case, or different context. Specifically less developed countries are more relaxed in relation to the control of corruption, trying to avoid bureaucracy burdens for potential investors who could stimulate economic growth and reduction of poverty. As the corrupt practices cannot be completely eradicated, we agree with the view of Brinkerhoff and Goldsmith (2005) that the efforts of the anti-corruption strategies and governance reforms should be directed towards those types of corruption that are most harmful. A lot of the focus of development assistance has been placed on the participation of civil society in order to advance the fight against corruption and create alternative systems to provide services. The findings reveal that the proposed approach to corruption control does not provide adequate results in achieving the goals of sustainable development. These findings also confirm the thesis expressed by Murray and Overton (2011) that NGOs can be equally corrupt and work in their own interest. Such interpretation is quite correct, bearing in mind that a number of non-governmental organizations are aimed at obtaining financial resources for their own existence without a long-term approach in the implementation of development projects. A similar situation exists with the funding of projects aimed at improving the rule of law. The research results give support to Moloney (2009) who indicates an anomaly in the sense that the increase in the amount of money to finance projects in the field of rule of law causes a considerable reduction in indicators of the rule of law

Although the principles of post-Washington Consensus neoliberal reforms have shifted focus from liberalization and deregulation to good governance, re-focusing attention on the new direction is just a way to overcome the failure of neoliberal development policies. In this way the economic growth is maintained as the primary goal of the neoliberal reform even trough good governance reforms neglecting the need of balanced approach toward sustainability. Therefore, it is indeed reasonable to ask questions about the role of good governance in achieving sustainable development, at least in terms of the model promoted by the neoliberal agenda. Thus, we fully agree with Demmers 
(2004) who believes that the Western policy of development aid and development thinking, based on the global neo-liberalism, is not the recipe for development because it deepens the levels of poverty and inequality and contributes to new conflicts in the world.

\section{Conclusion}

Regardless of certain evidence that at first glance may indicate the connection between good governance and sustainable development, the existing literature also shows different points of view on the real effects of good governance. The reason for the critical analysis of the impact of good governance on sustainable development can be found in over-generalization of these ties without taking into consideration the specific characteristics of specific country or region. By accessing the "one size fits all" approach many significant problems have occurred in the implementation of the public sector reforms leading to the ineffectiveness of development aid and spending limited financial resources without achieving the objectives of sustainable development. In this sense, the multi-dimensional nature of the model of good governance and the heterogeneity of different goals of sustainable development are not recognized. Although our findings confirm the existence of the effects of good governance on selected indicators of sustainable development, the in-depth analysis of these relationships shows a more colored picture. The empirical study of the effects of good governance dimensions on the selected indicators of sustainable development, based on cross-sectional research from the perspective of different categories of countries, shows different statistical significance, intensity and direction of impact. The empirical findings ask for a significant review of the reform agenda of public governance. These findings are very challenging for the principles of post-Washington Consensus aimed at promoting model of good governance as a universal remedy for development in countries with different characteristics.

\section{References}

Argyriades, Demetrios (2006). Good governance, professionalism, ethics and responsibility. SAGE Publications: International Review of Administrative Sciences, Vol. 72(2), p. 155-170;

Ayub, Mahmood (2013). Poverty and Inequality. SAGE Publications: Global Journal of Emerging Market Economies, Vol. 3(3), p. 329-346

Banik, Nilanjan; Yoonus, C.A. (2012). Trade as an Answer to Sustainable Economic Growth-The ECOWAS Story. SAGE Publications: Global Business Review, Vol. 13(2), p. 311-326

Bosselmann, Klaus; Engel, Ron; Taylor, Prue (2008). Governance for Sustainability: Issues, Challenges, Successes. Gland (Switzerland): International Union for Conservation of Nature

Brinkerhoff, Derick W.; Goldsmith, Arthur A. (2005). Institutional Dualism and International Development: A Revisionist Interpretation of Good Governance. SAGE Publications: Administration \& Society, Vol. 37(2), p. 199-224

Coate, Roger A.; Alger, Chadwick F.; Lipschutz, Ronnie D. (1996). The United Nations and Civil Society: Creative Partnerships for Sustainable Development. SAGE Publications: Alternatives: Global, Local, Political, Vol. 21, p. 93-122

Craig, David; Porter, Douglas (2006). Development beyond neoliberalism?: Governance, poverty reduction and political economy. Cambridge University Press 
De Angelis, Massimo (2003). Neoliberal Governance, Reproduction and Accumulation. The Commoner, N.7, Spring/Summer 2003

De La Barra, Ximena (2006). Who Owes and Who Pays? The Accumulated Debt of Neoliberalism. SAGE Publications: Critical Sociology, Vol. 32(1), p. 125-161

Demmers, Jolle (2004). Global neoliberalisation and violent conflict: Some concluding thoughts. In Demmers, Jolle; Jilberto, Alex E. Fernández; Hogenboom, Barbara [eds.] (2004). Good Governance in the Era of Global Neoliberalism: Conflict and depolitisation in Latin America, Eastern Europe, Asia and Africa. London \& New York: Routledge

Demmers, Jolle; Jilberto, Alex E. Fernández; Hogenboom, Barbara (2004). Good governance and democracy in a world of neoliberal regimes. In Demmers, Jolle; Jilberto, Alex E. Fernández; Hogenboom, Barbara [eds.] (2004). Good Governance in the Era of Global Neoliberalism: Conflict and depolitisation in Latin America, Eastern Europe, Asia and Africa. London \& New York: Routledge

Fine, Ben (2003). Neither the Washington nor the post-Washington consensus. In Fine, Ben; Lapavitsas, Costas; Pincus, Jonathan [Eds.] (2003). Development Policy in the Twenty-First Century: Beyond the Post-Washington Consensus. London \& New York: Routledge

Gore, Charles (2000). The Rise and Fall of the Washington Consensus as a Paradigm for Developing Countries. World Development, Vol. 28(5), p. 789-804

Grindle, Merilee S. (2004). Good Enough Governance: Poverty Reduction and Reform in Developing Countries. Governance: An International Journal of Policy, Administration and Institutions, Vol. 17(4), p. 525-548.

Grindle, Merilee S. (2010). Good Governance: The Inflation of an Idea. Harvard Kennedy School, Faculty Research Working Paper Series, RWP10-023

Haque, M. Shamsul (1999). The Fate of Sustainable Development Under Neo-Liberal Regimes in Developing Countries. SAGE Publications: International Political Science Review, Vol. 20(2), p. $197-218$

Hout, Wil (2007). The Politics of Aid Selectivity: Good governance criteria in World Bank, US and Dutch development assistance. London \& New York: Routledge

Kemp, René; Parto, Saeed (2005). Governance for sustainable development: moving from theory to practice. Inderscience Publishers: International Journal for Sustainable Development, Vol. 8(1/2), p. 12-30

Khan, Mushtaq H. (2007). Governance, Economic Growth and Development since the 1960s. New York: UNDESA Working Paper No. 54, ST/ESA/2007/DWP/54

Kim, Pan Suk (2009). Introduction: The aid - good governance conundrum: searching for more realistic discourse. SAGE Publications: International Review of Administrative Sciences, Vol. 75(4), p. 555-563;

Kioe Sheng, Yap (2010). Good Urban Governance in Southeast Asia. SAGE Publications: Environment and Urbanization Asia, Vol. 1(2), p. 131-147

Krugamn, Paul; Wels, Robin (2013). Economics. Princton University, Worth Publishers, third edition

Lafferty, William M. (1999). Introduction: The Pursuit of Sustainable Development-Concepts, Policies and Arenas. SAGE Publications: International Political Science Review, Vol. 20(2), p. 123-128

Leichtová, Magdaléna; Piknerová, Linda; Ponízilová, Martina (2007). Limits of Human Development in Weak States: A Conceptual Evaluation. SAGE Publications: International Studies, Vol. 49(1/2), p. $1-22$;

Margheritis, Ana; Pereira, Anthony W. (2007). The Neoliberal Turn in Latin America: The Cycle of Ideas and the Search for an Alternative. SAGE Publications: Latin American Perspectives, Vol. 34(3), p. 25-48;

Minujin, Alberto; Vandemoortele, Jan; Delamonica, Enrique (2002). Economic growth, poverty and children. SAGE Publications: Environment and Urbanization, Vol. 14(2), p. 23-43

Mitlin, Diana (1992). Sustainable Development: a Guide to the Literature. SAGE Publications: Environment and Urbanization, Vol. 4(1), p. 111-124

Moloney, Kim (2009). Public administration and governance: a sector-level analysis of World Bank aid. SAGE Publications: International Review of Administrative Sciences, Vol. 75(4), p. 609-627;

Murray, Warwick E.; Overton, John D. (2011). Neoliberalism is dead, long live neoliberalism? Neostructuralism and the international aid regime of the 2000s. SAGE Publications: Progress in Development Studies, Vol. 11(4), p. 307-319 
Nayyar, Deepak (2006). Development through Globalization? Helsinki: United Nations University, Research Paper No. 2006/29

Öniş, Ziya; Şenses, Fikret (2003). Rethinking the Emerging Post-Washington Consensus: A Critical Appraisal. Ankara: Economic Research Center, ECR Working Paper in Economics 3/09

Parnini, Syeda Naushin (2009). Public Sector Reform and Good Governance: The Impact of Foreign Aid on Bangladesh. SAGE Publications: Journal of Asian and African Studies, Vol. 44(5), p. 553-575;

Plewes, Betty; Sreenivasan, Gauri; Draimin, Tim (1996). Sustainable Human Development as a Global Framework. SAGE Publications: International Journal, Vol. 51, p. 211-234

Rees, William E. (2002). Globalization and Sustainability: Conflict or Convergence? SAGE Publications: Bulletin of Science Technology \& Society, Vol. 22(4), p. 249-268

Rodrik, Dani (2008). Thinking about Governance. In North, Douglass C.; Acemoglu, Daron; Fukuyama, Francis; Rodrik, Dani (2008). Governance, Growth and Development Decision-making. Washington: The World Bank

Sharma, S. K. (2001). Governance for realising a sustainable society. SAGE Publications: Social Change, Vol. $31(1 / 2)$, p. $165-173$

Sharma, Shalendra D. (2007). Democracy, Good Governance, and Economic Development. Taiwan Journal of Democracy, Vol. 3(1), p. 29-62

Shepherd, Andrew (2000). Governance, Good Government and Poverty Reduction. SAGE, International Review of Administrative Science, Vol. 66(2), p. 269-284

Shylendra, H.S.; Bhirdikar, Kishore (2005). 'Good Governance' and Poverty Alleviation Programmes: A Critical Analysis of the Swarnjayanti Gram Swarozgar Yojana. SAGE Publications: International Journal of Rural Management, Vol. 1(2), p. 203-221

Soubbotina, Tatyana (2004). Beyond Economic Growth: An Introduction to Sustainable Development. Washington: The World Bank, 2nd edition

Stiglitz, Joseph (1998). Towards a New Paradigm for Development. UNCTAD: 9th Raul Prebisch Lecture

Stiglitz, Joseph (2002). Globalization and its discontents. London: Penguin

Thomas, Vinod (2009). Income Disparity and Growth. SAGE Publications: Global Journal of Emerging Market Economies, Vol. 1(1), p. 63-86

Todaro, Michael; Smith, Stephen (2003). Economic development. Boston: Addison Wesley

UNDESA (2012). World Economic Situation and Prospects. New York: United Nations Department of Economic and Social Affairs - Division for Sustainable Development

UNDESA; UNDP; UNESCO (2012). Governance and development: Thematic Think Piece. New York: UN System Task Team on the post-2015 UN Development agenda

UNWCED (1987). Our common future: World Commission on Environment and Development. Oxford: Oxford University Press

Wang, Greg G.; Korte, Russell F.; Sun, Judy Y. (2008). Development Economics: A Foundation for HRD Policy Studies in Developing Countries. SAGE Publications: Advances in Developing Human Resources, Vol. 10(6), p. 848-862

Yamaguchi, Hideka (2003). Whose Sustainable Development? An Analysis of Japanese Foreign Aid Policy and Funding for Energy Sector Projects. SAGE Publications: Bulletin of Science Technology \& Society, Vol. 23(4), p. 302-310

Yi, Dae Jin; Woo, Jun Hee (2014). Democracy, policy, and inequality: Efforts and consequences in the developing world. SAGE Publications: International Political Science Review, p.1-18 